\title{
Phylloseptin-1 is Leishmanicidal for Amastigotes of Leishmania amazonensis Inside Infected Macrophages
}

\author{
Selma A. S. Kückelhaus ${ }^{1, *}$, Daniela Sant'Ana de Aquino ${ }^{1}$, Tatiana K. Borges ${ }^{2} \oplus$, \\ Daniel C. Moreira ${ }^{1}\left(\mathbb{D}\right.$, Luciana de Magalhães Leite ${ }^{1} \mathbb{(}$, Maria Imaculada Muniz-Junqueira ${ }^{2}{ }^{(\mathbb{B}}$, \\ Carlos S. Kückelhaus ${ }^{2}$, Gustavo A. Sierra Romero ${ }^{3}\left(\mathbb{D}\right.$, Maura V. Prates ${ }^{4}$, Carlos Bloch Jr. ${ }^{4}$ (D) \\ and José Roberto S. A. Leite 1,5 (D) \\ 1 Núcleo de Pesquisa em Morfologia e Imunologia Aplicada, NuPMIA, Área de Morfologia, \\ Faculdade de Medicina, FM, Universidade de Brasília, Brasília, DF 70910900, Brazil; \\ danisantana.aquino@gmail.com (D.S.d.A.); moreiradc@unb.br (D.C.M.); \\ medvet.luciana@gmail.com (L.d.M.L.); jrsaleite@gmail.com (J.R.S.A.L.) \\ 2 Laboratório de Imunologia Celular, Núcleo de Pesquisa em Morfologia e Imunologia Aplicada, NuPMIA, \\ Faculdade de Medicina, FM, Universidade de Brasília, Brasília, DF 70910900, Brazil; \\ tatianakarlab@gmail.com (T.K.B.); mimjunqueira@gmail.com (M.I.M.-J.) \\ 3 Laboratório de Leishmaniose, Núcleo de Medicina Tropical, Universidade de Brasília, \\ Brasília, DF 70910900, Brazil; cscarlossantos@gmail.com (C.S.K.); gromero@unb.br (G.A.S.R.) \\ 4 Laboratório de Espectrometria de Massa, LEM, EMBRAPA Recursos Genéticos e Biotecnologia, \\ Brasília, DF 70770900, Brazil; maura.prates@embrapa.br (M.V.P.); carlos.bloch@embrapa.br (C.B.J) \\ 5 Bioprospectum, Lda, Parque Tecnológico da Universidade do Porto, UPTEC, 4200135 Porto, Portugal \\ * Correspondence: selmask@gmail.com; Tel.: +55-61-3107-1921
}

Received: 28 May 2020; Accepted: 1 July 2020; Published: 6 July 2020

check for updates

\begin{abstract}
Leishmania protozoans are the causal agents of neglected diseases that represent an important public health issue worldwide. The growing occurrence of drug-resistant strains of Leishmania and severe side effects of available treatments represent an important challenge for the leishmaniases treatment. We have previously reported the leishmanicidal activity of phylloseptin-1 (PSN-1), a peptide found in the skin secretion of Phyllomedusa azurea (=Pithecopus azureus), against Leishmania amazonensis promastigotes. However, its impact on the amastigote form of L. amazonensis and its impact on infected macrophages are unknown. In this work, we evaluated the effects of PSN-1 on amastigotes of L. amazonensis inside macrophages infected in vitro. We assessed the production of hydrogen peroxide and nitric oxide, as well as the levels of inflammatory and immunomodulatory markers (TGF- $\beta$, TNF- $\alpha$ and IL-12), in infected and non-infected macrophages treated with PSN-1. Treatment with PSN-1 decreased the number of infected cells and the number of ingested amastigotes per cell when compared with the untreated cells. At $32 \mu \mathrm{M}(64 \mu \mathrm{g} / \mathrm{mL})$, PSN-1 reduced hydrogen peroxide levels in both infected and uninfected macrophages, whereas it had little effect on NO production or TGF- $\beta$ release. The effect of PSN-1 on IL-12 and TNF- $\alpha$ secretion depended on its concentration, but, in general, their levels tended to increase as PSN-1 concentration increased. Further in vitro and in vivo studies are needed to clarify the mechanisms of action of PSN-1 and its interaction with the immune system aiming to develop pharmacological applications.
\end{abstract}

Keywords: antimicrobial peptides; cytokine; leishmaniasis; oxidative stress

\section{Introduction}

Protozoans of the Leishmania genus are the causal agents of important but neglected tropical diseases that affect $0.7-1$ million people each year worldwide [1-4]. Leishmaniases are classified as cutaneous, mucosal and visceral, depending on the clinical manifestations. The first form is characterized 
by self-healing cutaneous ulcers, the second by severe disfiguration of mucosal regions and the last by its effect on internal organs such as liver and spleen [5]. For a long time, the administration of pentavalent antimony (SbV) has been the leading treatment for leishmaniasis [6], regardless of its severe side effects [7]. Indeed, the treatment of leishmaniases is associated with undesirable side effects, including toxicity, high cost, long periods of treatment and inconvenient route of administration [8]. Noteworthy, parasite resistance is an important issue and, as it happens for bacteria, the occurrence of drug-resistant strains of protozoa represents an important challenge for the leishmaniases treatment and public health. These factors motivate the development of novel anti-leishmanial treatments.

Antimicrobial peptides have emerged as attractive alternatives for the development of new drugs. Peptides present relative low toxicity $[9,10]$ and a broad antibiotic action against pathogens, including viruses [11], bacteria [12], fungi [13] and protozoa [14,15]. The amphibians' skin is a natural source of such peptides; therefore, many research groups have investigated it, looking for novel bioactive molecules to treat human diseases. In the case of leishmaniasis, we have previously reported that phylloseptin-1 (PSN-1), formerly known as PS-1 [16], has a strong activity against Leishmania amazonensis promastigotes [10]. This cationic peptide (at physiological $\mathrm{pH}$ ) was first isolated from the cutaneous secretion from Phyllomedusa azurea (renamed for Pithecopus azureus (Cope, 1862)) (Anura: Hylidae) and belongs to the phylloseptins family (Figure 1a). PSN-1 has 19 amino acid residues (FLSLIPHAINAVSAIAKHN-NH ${ }_{2}$ ) and a molecular weight of $2016 \mathrm{Da}$. While PSN-1 shows low toxicity and negligible hemolytic effects [17], there are several reports about its antimicrobial activities. For instance, it displays significant activity against Plasmodium falciparum [17], gram-positive bacteria [9], gram-negative bacteria [9], bacterial biofilm [18] and yeast [19].

Notably, PSN-1 is able to strongly suppress the growth of three leishmania species, Leishmania infantum, L. major and L. braziliensis in their promastigote stage $[17,20]$. Since Leishmania amastigotes are the main form found inside macrophages during human infections, it is urgent to evaluate the effect of PSN-1 on this form of L. amazonensis to better understand the potential role of PSN-1 as an anti-leishmanial drug. In this study, we assessed the effects of the PSN-1 peptide on amastigote-infected peritoneal macrophages. We evaluated infection index, hydrogen peroxide production, nitric oxide generation and levels of the immunomodulatory IL- 12 and TGF- $\beta$, and the level of the inflammatory TNF- $\alpha$. This approach is likely to be more clinically relevant than that using promastigotes, since this is the form present inside macrophages, which are the main cells involved in the pathogenesis of the leishmaniases.

\section{Materials and Methods}

\subsection{Phylloseptin-1 Synthesis and Isolation}

Amidated PSN-1 (FLSLIPHAINAVSAIAKHN-NH ${ }_{2}$; Figure 1) was synthesized on a Prelude Peptide Synthesizer (Protein Technologies Inc. Tucson, AZ, USA). F-moc amino acids and F-moc-Rink-Amide-MBHA resin were purchased from Peptides International (Louisville, KY, USA). After synthesis, the peptide was cleaved from the resin by a cocktail containing trifluoracetic acid (TFA), triisopropylsilane (TIS) and water, 95:5:5 (v/v/v). The product was precipitated by adding cooled diisopropyl ether, and the resulting crude extract was freeze-dried. The thin-white powder obtained was mass analyzed (MicrOTOF-Q II, Bruker Daltonics, Bremen, Germany) in order to check the peptide integrity.

Aliquots of $10 \mathrm{mg}$ from the lyophilized and filtered product were injected into a preparative Jupiter $\mathrm{C}_{18}$ column (Phenomenex, Torrance, CA, USA) coupled to an HPLC Prominence System (Shimadzu Corporation, Kyoto, Japan) to isolate the active peptide fraction from by-products. The peptide elution was monitored at 216 and $280 \mathrm{~nm}$, under a step-optimized gradient of acetonitrile and water (TFA $0.1 \%$ ); from $0 \%$ to $100 \%$ acetonitrile. Molecular mass and PSN-1 purity were checked by MALDI/TOF-TOF-MS on an Ultraflex II (Bruker Daltonics, Bremen, Germany). 
Stock solutions of PSN-1 (prepared in phosphate-buffered saline) had their concentration checked and adjusted using ultraviolet spectrophotometry [21,22]. Cells were treated with PSN-1 at the final concentrations of 2,16 or $64 \mu \mathrm{g} / \mathrm{mL}$, which correspond to 1,8 or $32 \mu \mathrm{M}$, respectively. These concentrations were chosen based on our previous work [17].

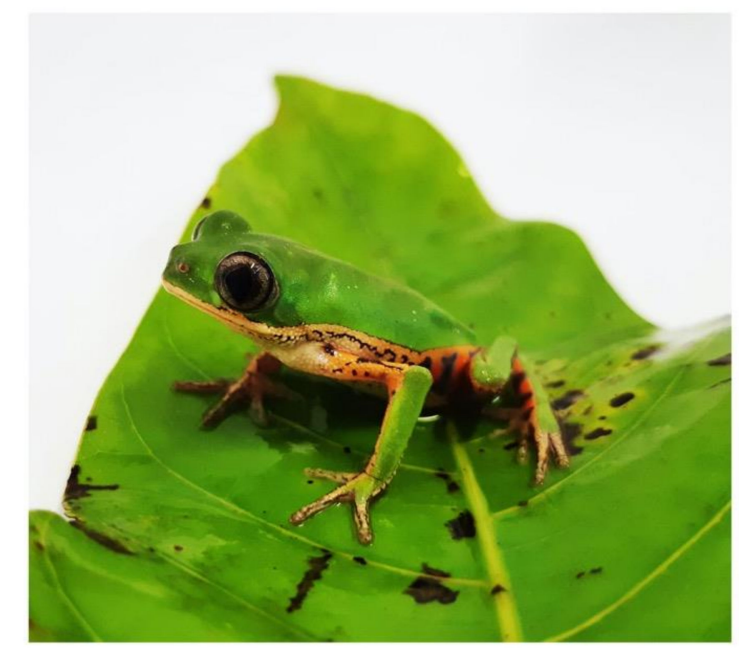

(a)

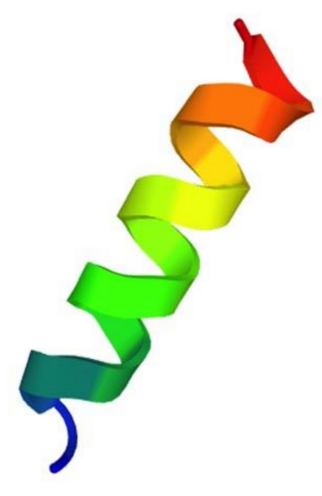

(b)

Figure 1. Phyllomedusa azurea (renamed for Pithecopus azureus (Cope, 1862)) (Anura: Hylidae) and the phylloseptin-1 (PSN-1) peptide. (a) Adult specimen of P. azurea, whose skin secretion was the first source where PSN-1 was identified (Photo: Eder A. Barbosa). (b) Tridimensional representation of PSN-1 predicted by PEP-FOLD 3.5/De novo peptide structure prediction [23].

\subsection{Leishmania amazonensis}

The isolate MHOM/BR/pH8 of Leishmania amazonensis was obtained from the Laboratory of Leishmaniasis of the Institute of Tropical Medicine, University of Brasilia, Brazil. It was cryopreserved in liquid nitrogen until transfer to an NNN medium and cultured at $24{ }^{\circ} \mathrm{C}$ for $48 \mathrm{~h}$. In sequence, a small aliquot was added to Schneider culture medium, supplemented with $20 \%$ heat-inactivated fetal calf serum (Sigma Aldrich, St. Louis, MO, USA) and gentamicin sulphate (40 mg/mL; Schering Plough, São Paulo, Brazil), and cultured until the log phase was reached. The axenic amastigotes were obtained by maintaining the suspension incubated at $37^{\circ} \mathrm{C}$ for $96 \mathrm{~h}$ [24]. After monitoring different cell forms by microscopic analyses, only amastigote L. amazonensis cells were used to infect macrophages.

\subsection{Animals}

Female adult Swiss mice $(n=8)$ (Faculty of Medicine, University of Brasilia, Brazil) at 2 months of age and weighting $35 \pm 5 \mathrm{~g}$ were maintained at $12 \mathrm{~h}$ dark/light cycles. Animals had access to balanced food and water ad libitum and were kept at room temperature until experiments. The Animal Research Ethical Committee of the Brasília University approved the experimental protocol (process number 51002/2013).

\subsection{Macrophage Infection}

Mouse macrophages were obtained by washing the peritoneal cavity with $10 \mathrm{~mL}$ of cold phosphate-buffered saline (PBS, pH 7.2). Cells were washed with cold PBS (200× $g, 10 \mathrm{~min})$, quantified in hemocytometer and suspended into cold RPMI 1640 medium (Sigma, St. Louis, MO, USA), pH 7.2, supplemented with 20 mM HEPES (Sigma), 2 mM glutamine (Sigma) and $2.5 \mathrm{mg} / \mathrm{dl}$ gentamycin. Viability was assessed in hematocytometer with $0.05 \%$ nigrosin solution in PBS, pH 7.2; viability was always higher than $97 \%$. Then, samples of $2 \times 10^{5}$ macrophages in RPMI 1640 were placed, in duplicate, 
on $13 \mathrm{~mm}$-diameter glass coverslips in 24-well plastic plates (Linbro, Corning, NY, USA), incubated for $2 \mathrm{~h}$ in a wet chamber, at $37^{\circ} \mathrm{C}$, in the presence of $5 \% \mathrm{CO}_{2}$ in air to allow adherence of macrophages onto the glass. Then, the coverslips were rinsed with $\mathrm{PBS}, \mathrm{pH} 7.2$, at $37^{\circ} \mathrm{C}$, to eliminate non-adhered cells. Adherent cells ( $>98 \%$ macrophages) were incubated with $10^{6}$ axenic amastigotes forms of L. amazonensis per well, suspended in $500 \mu \mathrm{L}$ of RPMI 1640, supplemented with $10 \%$ inactivated fetal calf serum (Gibco), in a wet chamber for $8 \mathrm{~h}$ at $37^{\circ} \mathrm{C}$, in $5 \% \mathrm{CO}_{2}$ in air. The preparations were then rinsed with PBS at $37^{\circ} \mathrm{C}$ to eliminate non-phagocytosed Leishmania. After that, infected macrophages were incubated with different concentrations of PSN-1 $(0,1,8$ or $32 \mu \mathrm{M})$ for $2 \mathrm{~h}$, rinsed with PBS, fixed with absolute methanol and stained with $10 \%$ buffered Giemsa solution (pH 7.2). The number of amastigotes ingested by macrophages and the percentage of infected cells were assessed by optical microscopy. Parasites were considered as dead when their typical morphology was altered, and their integrity was lost. The infection index was calculated as the average number of ingested amastigotes multiplied by the percentage of macrophages engaged in phagocytosis [25]. Images of cells were obtained using a Zeiss Axio Lab.A1 microscope connected to an Axiocam ERc 5s image capture system (Carl Zeiss, Oberkochen, Germany).

\subsection{Nitric Oxide Production as Estimated by Nitrite Measurement}

Peritoneal cells were collected as described in Section 2.4 , seeded at $2 \times 10^{5}$ cells per well in 96 -well plates in $200 \mu \mathrm{L}$ of RPMI 1640 incomplete medium and incubated in a wet chamber at $37^{\circ} \mathrm{C}$ and $5 \%$ $\mathrm{CO}_{2}$ for $2 \mathrm{~h}$. Then, wells were washed three times with PBS at $37^{\circ} \mathrm{C}$, and $10^{6}$ amastigotes of Leishmania were added per well.

Plates were incubated under the previous conditions for $8 \mathrm{~h}$. Wells were washed three times with PBS at $37^{\circ} \mathrm{C}$ and then treated with $0,1,8$ or $32 \mu \mathrm{M}$ PSN-1 for $24 \mathrm{~h}$. Lipopolysaccharides from E. coli (055:b5, Sigma-Aldrich) at $20 \mathrm{ng} / \mathrm{mL}$ in PBS were used as a positive control. Plates were centrifuged at $200 \times g$ for $10 \mathrm{~min}$ and $100 \mu \mathrm{L}$ of the supernatants were transferred to another plate and incubated $v / v$ with Griess reagent ( $1 \%$ sulphanilamide/0.1\% N-1-naphthylethylene diaminedihydrochloride $/ 2.5 \%$ $\mathrm{H}_{3} \mathrm{PO}_{4}$ ) at room temperature for $10 \mathrm{~min}$. [26]. Then, the plate was read at $540 \mathrm{~nm}$, (SpectraMax ${ }^{\circledR}$ Plus 384; Molecular Devices, Sunnyvale, CA, USA). Blank was done in air. Results were expressed as $\mu \mathrm{M} \mathrm{NO}_{2}{ }^{-}$.

\subsection{Hydrogen Peroxide Production}

Peritoneal cells were collected and incubated with Leishmania amastigotes as described in Section 2.5. Macrophages were then washed and incubated with $0,1,8$ or $32 \mu \mathrm{M}$ PSN-1 in $140 \mu \mathrm{L}$ of a solution containing $5.5 \mathrm{mM}$ dextrose, $0.5 \mathrm{mM}$ phenol red and $19 \mathrm{U} / \mathrm{mL}$ of horseradish peroxidase type $2 \mathrm{RZ}$ 1.3 (Sigma, St. Louis, MO, USA) and $100 \mathrm{nM}$ phorbol myristate acetate (PMA) (Sigma, St. Louis, $\mathrm{MO}$, USA), for $1 \mathrm{~h}$. The reaction was stopped by adding $10 \mu \mathrm{L}$ of $1 \mathrm{M} \mathrm{NaOH} /$ well. The plate was read at $620 \mathrm{~nm}$ in a microplate reader (SpectraMax ${ }^{\circledR}$ Plus 384; Molecular Devices, Sunnyvale, CA, USA) [27]. Blank was done in air. Results were expressed as $\mu \mathrm{M} \mathrm{H}_{2} \mathrm{O}_{2} / 2 \times 10^{5}$ macrophages/ $\mathrm{h}$.

\subsection{Cytokines}

Levels of transforming growth factor beta (TGF- $\beta$ ), tumor necrosis factor alpha (TNF- $\alpha$ ), and interleukin-12 (IL-12) were assessed in supernatant of the cultures of peritoneal cells infected with Leishmania amastigotes and treated with PSN-1 $(0,1,8$ or $32 \mu \mathrm{M})$ for $2 \mathrm{~h}$, as described above, using commercially available ELISA kits (eBioscience, San Diego, CA, USA) as instructed by the manufacturer. The colorimetric reaction was read at a wavelength of $450 \mathrm{~nm}$ in a microplate reader, (SpectraMax ${ }^{\circledR}$ Plus 384; Molecular Devices, Sunnyvale, CA, USA). Blank was done in air.

\subsection{Statistical Analysis}

Infection parameters results were analyzed using one-way ANOVA followed by Tukey's multiple comparison test. For the other measurements, data were analyzed using one-way ANOVA followed by 
Tukey's multiple comparisons test separately among infected or uninfected groups, or Kruskal-Wallis test followed by Dunn's multiple comparisons test for data distributed non-parametrically. Infected and uninfected groups were compared pairwise for each PSN-1 concentration using two-tailed unpaired t-test, or Mann-Whitney test. All data were tested for normality using the Kolmogorov-Smirnov test and with Bartlett test for equal variances. For all analyses, $p$ values lower than 0.05 were considered to indicate statistically significant differences. Statistical analyses and graphs were prepared using GraphPad Prism version 8 (GraphPad Software, La Jolla, CA, USA).

\section{Results}

Incubation of amastigote-infected macrophages with different concentrations of PSN-1 decreased the percentage of infected cells in a dose-dependent manner compared with the untreated control culture (Figure 2a,d). The number of ingested L. amazonensis per macrophage was higher in the control group than that in cells incubated with $32 \mu \mathrm{M}$, but it was not different from the other PSN-1 concentrations (Figure 2b). The infection index, calculated as the average number of ingested amastigotes multiplied by the percentage of infected cells, was higher in the control than that in cells treated with any PSN-1 concentration (Figure 2c). The treatment for $2 \mathrm{~h}$ with 1, 8 or $32 \mu \mathrm{M}$ of PSN-1 reduced the infection index of macrophages by $52 \%, 81 \%$ or $96 \%$, respectively. The number of non-infected macrophages in relation to PSN-1 concentration followed a logarithmic function trend (Figure 2d).

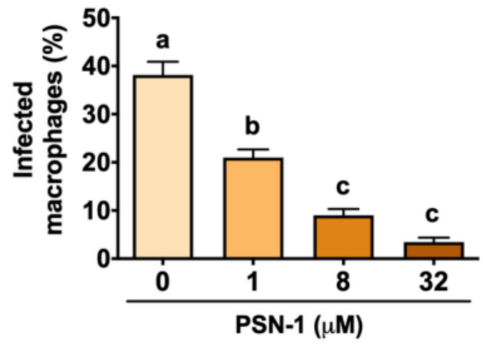

(a)

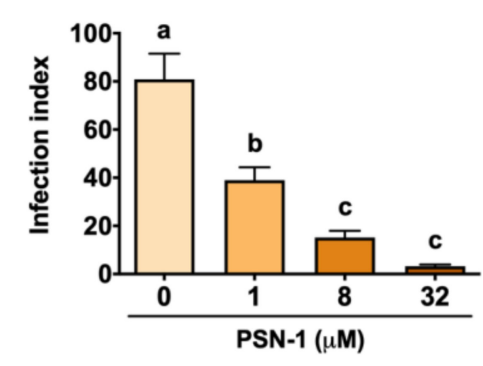

(c)

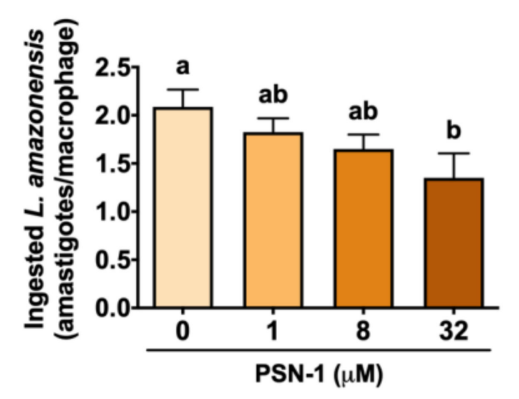

(b)

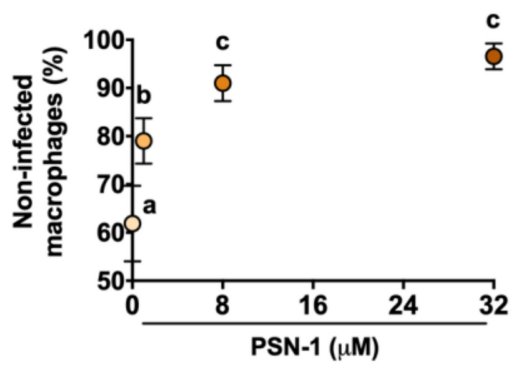

(d)

Figure 2. Effect of phylloseptin-1 (PSN-1) on axenic amastigotes of Leishmania amazonensis inside infected peritoneal macrophages. Cells were treated with different concentrations $(0,1,8$ or $32 \mu \mathrm{M})$ of PSN-1 for $2 \mathrm{~h}$. (a) Percentage of infected macrophages, (b) number of amastigotes ingested by each macrophage, (c) index of infection and (d) number of non-infected macrophages (\%) versus PSN-1 concentration. Data are presented as mean \pm SEM, except for $(\mathbf{d})$ where error bars stand for SD $(n=8$ repeated experiments). Different letters (i.e., groups that do not share any letter) indicate significant differences (one-way ANOVA followed by Tukey's multiple comparisons test; $p<0.05$ ).

Infected macrophages after $2 \mathrm{~h}$ of treatment with 8 or $32 \mu \mathrm{M}$ of PSN-1 are shown in Figure 3. Light microscopy evaluation showed normal morphology of amastigote in (a), while in (b), (c) and (d) amastigotes did not show homogeneous aspect. This appearance suggests that amastigotes are in process of disintegration. Probably, these fragments are parasite debris, suggesting PSN-1 have a lytic effect on the amastigote forms of L. amazonensis. 


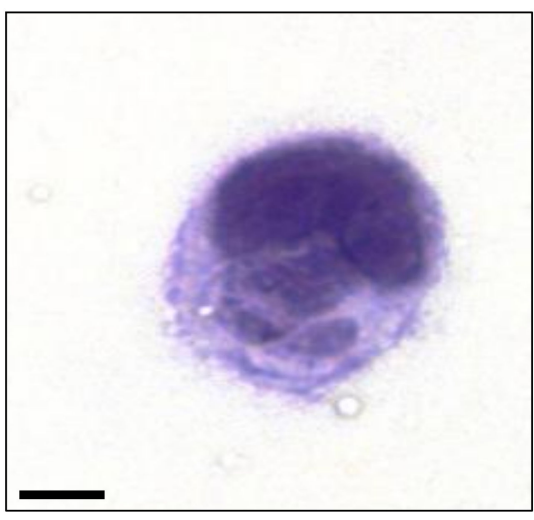

(a)

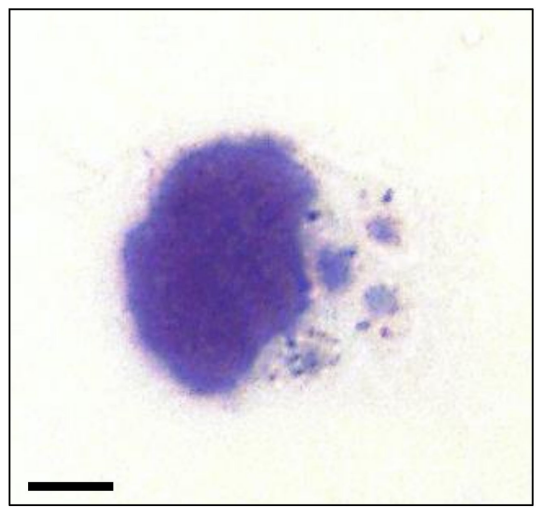

(c)

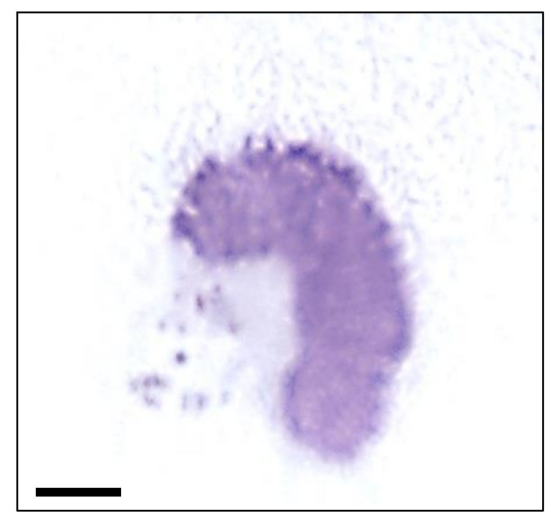

(b)

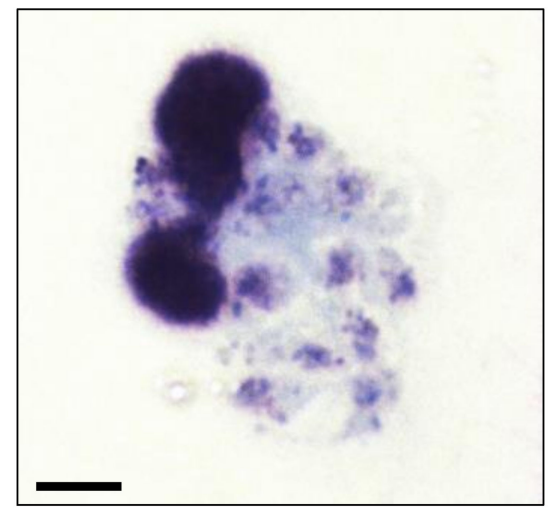

(d)

Figure 3. Photomicrography of amastigotes of Leishmania amazonensis inside infected-peritoneal macrophages non-treated (a) or treated with 1 (b), 8 (c) or 32 (d) $\mu$ M phylloseptin-1 (PSN-1). Non-normal morphology of amastigotes in (b), (c) and (d); normal morphology of amastigotes in the non-treated cells (a). Cells were stained with Giemsa. Magnification $=1000 \times$, Zeiss Axio Lab.A1 microscope. Scale bar $=4 \mu \mathrm{m}$.

Nitric oxide is a small, gaseous radical, produced enzymatically in macrophages from L-arginine and $\mathrm{O}_{2}$ by nitric oxide synthase. Nitrite is produced after reaction of $\mathrm{NO}$ with oxygen radicals and is assessed as an indirect measure of NO production [26,28-31]. Macrophages infected with L. amazonensis amastigotes without any treatment produced higher levels of NO than control non-infected cells (Figure 4) as indicated by higher nitrite levels. Similarly, stimulation with lipopolysaccharides elicited an increase in NO levels compared with control levels. In uninfected cells, PSN-1 slightly increased NO levels by $11 \%$ and $8 \%$ at 1 and $8 \mu \mathrm{M}$, respectively (Figure 4 ). In the case of hydrogen peroxide levels, there was no difference between infected and uninfected macrophages that were not treated with PSN-1 (Figure 4). Expectedly, exposure to PMA induced $\mathrm{H}_{2} \mathrm{O}_{2}$ production in macrophages (Figure 4). PSN-1 treatment had a significant effect on $\mathrm{H}_{2} \mathrm{O}_{2}$ levels only at the highest concentration (32 $\mu \mathrm{M})$, when it reduced $\mathrm{H}_{2} \mathrm{O}_{2}$ concentration by $18 \%$ and $24 \%$ in uninfected and infected macrophages, respectively, compared with control levels (Figure 4).

Although infection caused an increase in the variability of data on TGF- $\beta$ release by peritoneal macrophages, no differences were found between infected and uninfected macrophages or among macrophages treated with different concentrations of PSN-1 (Figure 5).

Amastigote infection alone did not cause significant changes in levels of TNF- $\alpha$ released by macrophages (Figure 6). Among uninfected cells, PSN-1 treatment at $8 \mu \mathrm{M}$ increased TNF- $\alpha$ levels significantly (by 105\%) compared with the untreated group (Figure 6). At high $(32 \mu \mathrm{M})$ and low $(1 \mu \mathrm{M})$ 
doses, however, PSN-1 treatment had no significant effect on TNF- $\alpha$ release compared with the group of cells treated with vehicle only (Figure 6).
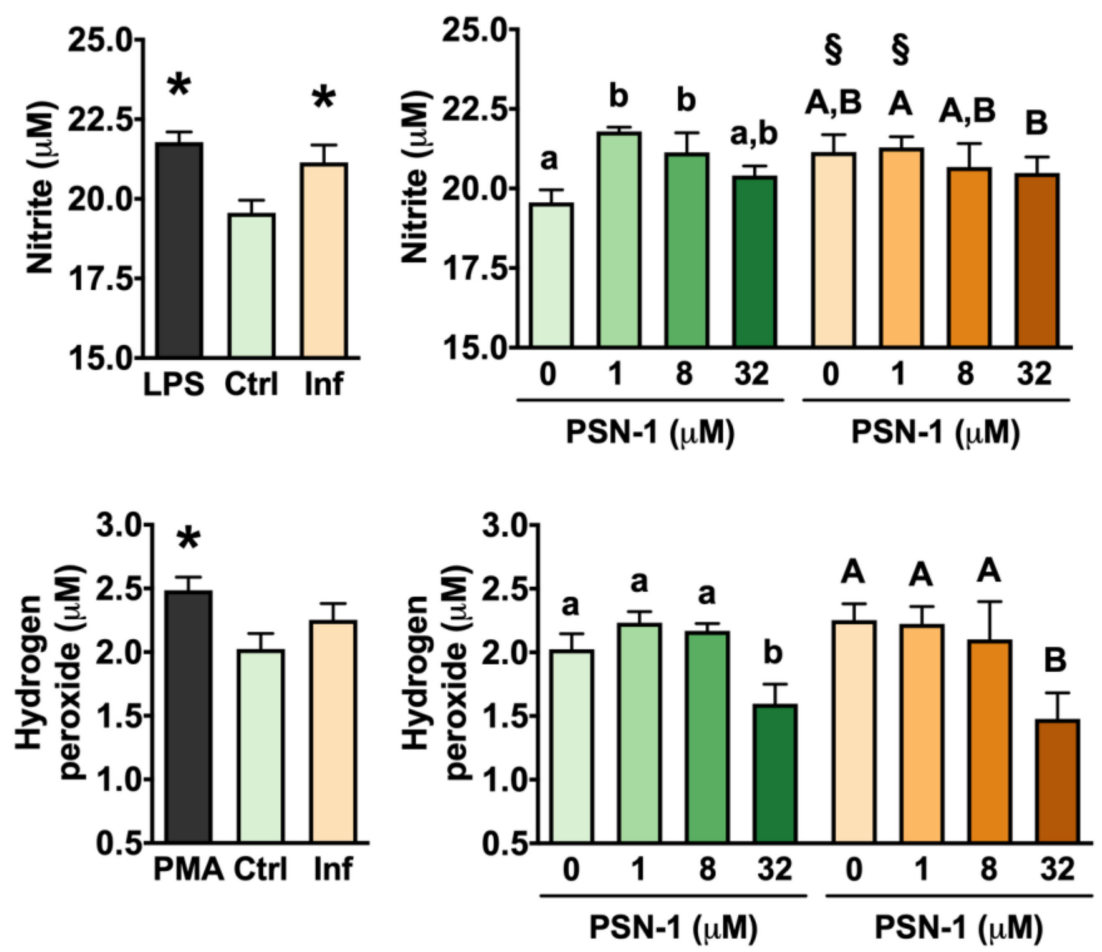

Figure 4. Nitric oxide production as estimated by nitrite measurement (top) and hydrogen peroxide levels (bottom) in peritoneal macrophages infected with axenic amastigotes of Leishmania amazonensis treated with different concentrations $(0,1,8$ or $32 \mu \mathrm{M})$ of phylloseptin-1 (PSN-1). Gray columns, positive control; green columns, uninfected macrophages; orange columns, infected macrophages. Data are presented as mean \pm SEM $(n=7-8$ repeated experiments). * Significantly different from the control group (unpaired $t$-test; $p<0.05$ ). $\$$ Significantly different from the respective uninfected group (unpaired $t$-test; $p<0.05$ ). Different lower case (uninfected) or upper case (infected) letters (i.e., groups that do not share any letter) indicate significant differences (one-way ANOVA followed by Tukey's multiple comparisons test; $p<0.05)$.
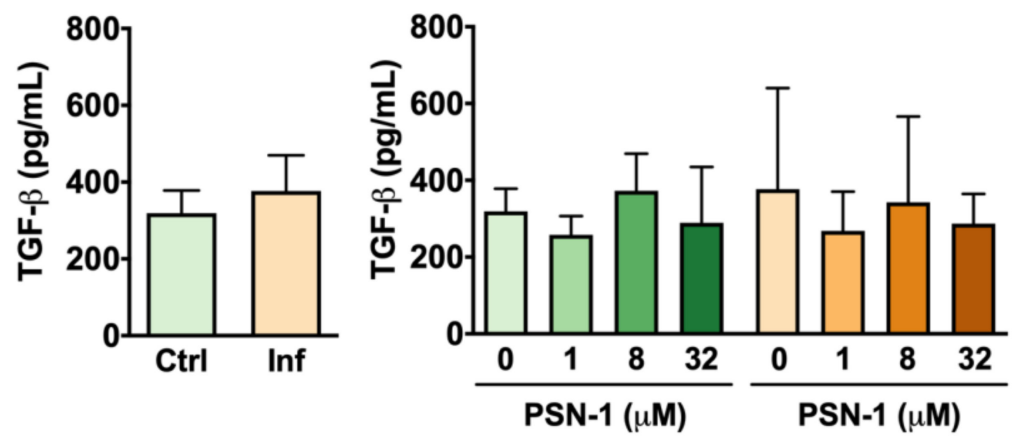

Figure 5. Transforming growth factor beta (TGF- $\beta$ ) levels $(\mathrm{pg} / \mathrm{mL})$ in the supernatant of peritoneal macrophages infected with axenic amastigotes of Leishmania amazonensis treated with different concentrations $(0,1,8$ or $32 \mu \mathrm{M})$ of phylloseptin-1 (PSN-1). Green columns, uninfected macrophages; orange columns, infected macrophages. Data are presented as mean \pm SEM $(n=7-8$ repeated experiments). No significant differences were detected. 

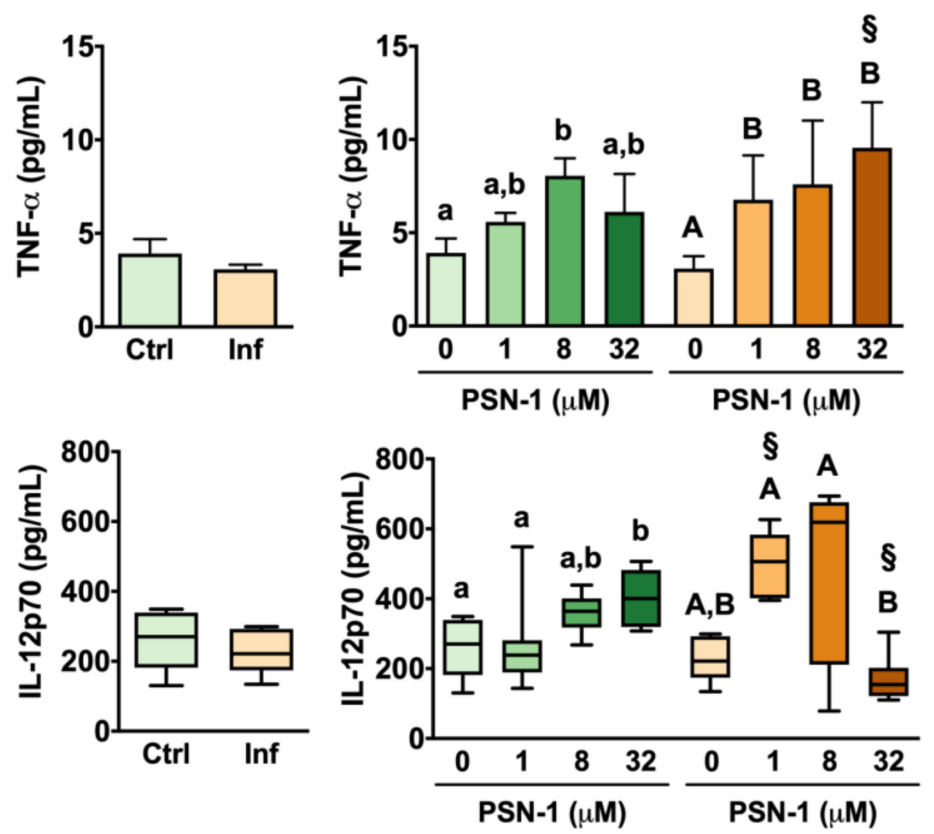

Figure 6. Tumor necrosis factor alpha (TNF- $\alpha$; top) and interleukin-12 (IL-12; bottom) levels (pg/mL) in the supernatant of peritoneal macrophages infected with axenic amastigotes of Leishmania amazonensis treated with different concentrations $(0,1,8$ or $32 \mu \mathrm{M})$ of phylloseptin-1 (PSN-1). Green columns, uninfected macrophages; orange columns, infected macrophages. Data are presented as mean \pm SEM ( $n=6-8$ repeated experiments) for TNF- $\alpha$ and as box plot for IL-12 $(n=7-8$ repeated experiments). $\S$ Significantly different from the respective uninfected group (unpaired $t$-test; $p<0.05$ ). Different lower case (uninfected) or upper case (infected) letters (i.e., groups that do not share any letter) indicate significant differences (one-way ANOVA followed by Tukey's multiple comparisons test; $p<0.05)$.

In the case of infected macrophages, TNF- $\alpha$ levels increased by $120 \%$ in the group treated with $1 \mu \mathrm{M}$ compared with the untreated infected group (Figure 6). TNF- $\alpha$ release was also significantly higher in infected macrophages treated with 8 and $32 \mu \mathrm{M}$ than in infected macrophages treated with vehicle only (Figure 6). When infected and uninfected groups were compared, it was found that, at $32 \mu \mathrm{M}$, infected macrophages had $56 \%$ more TNF- $\alpha$ than uninfected cells treated with the same concentration (Figure 6).

Infection by L. amazonensis amastigotes did not cause significant changes in IL-12 levels released by peritoneal macrophages without treatment with PSN-1 (Figure 6). Among uninfected groups, PSN-1 treatment at $32 \mu \mathrm{M}$ caused a 56\% increase in IL-12 levels compared with macrophages treated with vehicle only (Figure 6). This same concentration did not cause any significant change in IL-12 release by infected macrophages. In fact, when macrophages were treated with $32 \mu \mathrm{M}$ PSN-1, IL-12 release was $132 \%$ higher in uninfected than in infected cells (Figure 6). In contrast, IL-12 levels were 87\% higher in infected macrophages treated with $1 \mu \mathrm{M}$ PSN-1 than in uninfected macrophages treated with $1 \mu \mathrm{M}$ PSN-1 (Figure 6).

\section{Discussion}

Leishmaniasis still represents an important public health concern worldwide. People affected by this disease are usually the poorest, and the occurrence of leishmaniasis has been associated with environmental changes, such as deforestation and urbanization. Available treatments to combat Leishmania parasites are scarce and widely known to be associated with severe side effects. As an attempt to develop novel pharmacological treatments, we had previously shown that the peptide PSN-1 has leishmanicidal activity against $L$. amazonensis promastigotes [17]. In the present study, we expanded 
our knowledge on the leishmanicidal activity of PSN-1 against L. amazonensis, this time using their intracellular amastigote form. We found that PSN-1 had a strong dose-dependent leishmanicidal effect on amastigote-infected macrophages.

During the biological cycle of Leishmania, soon after inoculation of promastigotes by phlebotomine into the host, the macrophage infection occurs. Then, these flagellated forms begin their transformation, within the parasitophorous vacuoles, to their non-flagellated forms amastigotes. Such change allows the avoidance of macrophage microbicide mechanisms. Therefore, it is key to target parasites in their amastigote form. Our results showed that the microbicidal effect of PSN-1 occurred in the three evaluated concentrations through the evaluation of the infection index of macrophages, when compared with macrophages without treatment. These concentrations caused a significant reduction in the percentage of infected cells, without causing apparent damage to macrophages, as observed by morphological aspect of these cells and by previous evaluation of functional responses after treatment with PSN-1 [10,17]. This agrees with previous studies that have shown the absence of toxicity of PSN-1, in vivo, by its intravenous administration at $480 \mu \mathrm{g} / \mathrm{mL}$ to Swiss mice [10] or in vitro treatment of peritoneal cells with concentrations higher than $200 \mu \mathrm{g} / \mathrm{mL}$ [17].

The membrane of mammalian cells is mainly composed of neutral phospholipids with a localized positive charge due to the presence of ionized groups [32], which reduce their interaction with cationic peptides. Although reduced, the interaction of cationic peptides with cell membranes may occur, but especially with increasing concentration of the peptide, causing structural disruption and increased permeability of these cell membranes [33-35]. Toxic effects of antimicrobial peptides related to their interaction to the cell membrane have been shown for melittin from bee [36], caribdoxin present in the venom of scorpions [37] and the temporin-L, from frogs of the genus Rana [38]. Although PSN-1 is a cationic peptide, we found no signs of significant damage to macrophages suggested by morphological aspect and previous observation $[10,17]$.

The morphological effects of PSN-1 on amastigotes suggest that the interaction of PSN-1 with the parasite occurred within the parasitophorous vacuoles. Possibly, the peptide initially interacted, by an unknown mechanism, with the cell membranes of macrophages and subsequently with the cell membrane of the parasite, as occurs for other antimicrobial peptides [39]. The antimicrobial activity of cationic peptides such as PSN-1 has been associated to the presence of phospholipids heavily loaded with positive charges, which allow them to interact with cell membranes of microorganisms, which commonly exhibit negative charges. Such interaction leads to changes in sodium and potassium flux and consequent increase in cell volume and disruption of the parasite cell [9,40-44]. Although we have not directly evaluated the mechanisms of action of PSN-1, we may speculate that the cellular debris observed within the macrophages may be a result from the formation of pores on the cell membrane as barrel-stave model [45]. According to this model, the pores are formed by the accumulation of monomeric peptides at a specific point of the membrane culminating with the drilling of the lipid bilayer [45].

The decrease in the infection rate in the cells treated with different concentrations of PSN-1 may also be explained by the interference of the peptide with the metabolic pathways of the parasite. For example, three analogs of magainin (MG-H1,-H2 and MG-F5W magainin-2) showed that these peptides decrease the production of ATP in a dose-dependent pattern in cultures of Leishmania donovani, causing the death of parasites [43]. Thus, it is possible that PSN-1 impaired oxidative phosphorylation and ATP production, leading to the shutdown of the metabolic processes and consequently the death of amastigotes; however, this explanation still requires experimental evidence.

To understand the molecular changes associated with the leishmanicidal effect of PSN-1 against L. amazonensis amastigotes, levels of key cytokines (TGF- $\beta$, TNF- $\alpha$ and IL-12) and the production of reactive species $\left(\mathrm{H}_{2} \mathrm{O}_{2}\right.$ and $\left.\mathrm{NO}\right)$ were assessed. These parameters were chosen based on the fact that the type of disease caused by Leishmania species depends on the genetics and immune response of the host. Parasites can trigger different host immune responses. The outcome of Leishmania infection depends on the development of polarized Th1 associated with resistance or Th2 responses with susceptibility. 
M1 macrophage and Th1 lymphocyte arm of immune response are associated with hydrogen peroxide and nitric oxide production. These two reactive species appear to be the main molecules involved in immune defense of the host. Inhibition of nitric oxide and oxygen radicals may be escape mechanisms of the parasite for their survival [46-51].

The increase in TNF- $\alpha$ indicates that PSN-1 also modulated the immune response. TNF- $\alpha$ enhances the defense response of macrophages against Leishmania [52]. Thus, it can be suggested that the increase in TNF- $\alpha$ release caused by PSN-1 might have participated in the destruction of the amastigotes inside macrophages observed in this work. It was also observed that PSN-1 upregulated IL-12p70 production in non-infected and up- and down-modulated IL-12 70 production in infected macrophages, depending on the concentration of PSN-1. This cytokine stimulates the Th1 immune response, which is the main type of immune response against Leishmania [53], suggesting that in vivo treatment with PSN-1 might improve an adaptive immune defense against the parasite. However, infected macrophages treated with $32 \mu \mathrm{M}$ PSN-1 decreased their IL-12p70 production. The cause of this effect is unclear, but some hypotheses may be considered. Cytokines are important modulators of an array of inflammatory and homeostatic processes. IL-10 is a potent negative regulator of IL-12, and activation of macrophages may stimulate regulatory mechanisms including the production of IL-10 $[54,55]$. Thus, the decrease in IL-12p70 production might be part of regulatory mechanisms of macrophages after infection that depended on PSN-1 concentration. Other possibility could be the stimulation via Toll-like receptor signaling by amastigotes of Leishmania combined with the concomitant treatment with high concentration of PSN-1, resulting in inhibition of IL-12p70 production instead of stimulation [56,57].

Noteworthy, at $32 \mu \mathrm{M}(64 \mu \mathrm{g} / \mathrm{mL})$, PSN-1 decreased $\mathrm{H}_{2} \mathrm{O}_{2}$ levels in both infected and uninfected macrophages. This indicates the potential antioxidant activity of this peptide in vivo. Nitric oxide and hydrogen peroxide are key players in the Leishmania killing process [30]; however, these molecules may also induce oxidative damage, so that these oxygen and nitrogen radicals may also contribute to the immunopathogenesis of leishmaniasis [52]. Treatment of amastigote-infected macrophages with PSN-1 decreased the production of such reactive molecules. Since PSN-1 has a potent leishmanicidal effect, it may be suggested that these immunomodulatory effects of the drug may favor the host instead of the parasite, by down-modulating the pathogenesis of the disease while the drug kill the parasite. Therefore, the mechanism of action of PSN-1 on Leishmania parasites and on innate and adaptive immune response of the host still warrants further research.

\section{Conclusions}

The effect of PSN-1 on amastigote forms of L. amazonensis further supports the potential use of the peptide for treatment of leishmaniasis. Its microbicidal effect occurred in a dose-dependent pattern, in which the maximum concentration $(32 \mu \mathrm{M} ; 64 \mu \mathrm{g} / \mathrm{mL})$ was able to reduce by $96 \%$ the infection index of macrophages. Although promising, further studies, in vitro and in animal models, are needed to clarify the mechanisms of action of PSN-1 and its interaction with the immune system.

Author Contributions: Conceptualization, S.A.S.K., T.K.B., L.D.M.L, M.I.M-.J., G.A.S.R., M.V.P., C.B.J. and J.R.S.A.L.; data curation, S.A.S.K.; formal analysis, S.A.S.K., D.S.d.A., D.C.M. and C.S.K; funding acquisition, S.A.S.K., M.I.M-.J., G.A.S.R., C.B.J. and J.R.S.A.L; investigation, S.A.S.K., D.S.d.A. and T.K.B.; methodology, S.A.S.K., D.S.d.A., T.K.B., L.D.M.L., M.I.M-J., C.S.K. and M.V.P; project administration, S.A.S.L., T.K.B., M.I.M.-J. G.A.S.R., C.B.J. and J.R.S.A.L.; resources, S.A.S.K., T.K.B., G.A.S.R., M.V.P., C.B.J. and J.R.S.A.L.; supervision, C.S.K.; visualization, D.C.M.; writing-original draft, S.A.S.K., D.S.d.A., T.K.B., D.C.M. and M.I.M-.J.; writing-review and editing, S.A.S.K.S., D.S.d.A., T.K.B., D.C.M., L.D.M.L., M.I.M-.J., G.A.S.R., M.V.P., C.B.J. and J.R.S.A.L. All authors have read and agreed to the published version of the manuscript.

Funding: This study was financed in part by the Coordenação de Aperfeiçoamento de Pessoal de Nível Superior-Brazil (CAPES)-Finance Code 001. D.C.M. (23106.134663/2019-62) and J.R.S.A.L. (23106.134632/2019-10) were recipients of grants from the Decanato de Pesquisa e Inovação (DPI, Edital 04/2019) of the University of Brasilia, UnB. Maria Imaculada Muniz-Junqueira is an investigator supported by the Conselho Nacional de Desenvolvimento Científico e Tecnológico (CNPq), Brazil (process number 308344/2016-2).

Acknowledgments: We are grateful to Lucas Souza Kückelhaus for the English revision of the manuscript.

Conflicts of Interest: The authors declare no conflicts of interest. 


\section{References}

1. Santos, D.O.; Coutinho, C.E.R.; Madeira, M.F.; Bottino, C.G.; Vieira, R.T.; Nascimento, S.B.; Bernardino, A.; Bourguignon, S.C.; Corte-Real, S.; Pinho, R.T.; et al. Leishmaniasis treatment-A challenge that remains: A review. Parasitol. Res. 2008, 103, 1-10. [CrossRef] [PubMed]

2. Greenwood, B.M.; Fidock, D.A.; Kyle, D.E.; Kappe, S.H.I.; Alonso, P.L.; Collins, F.H.; Duffy, P.E. Malaria: Progress, perils, and prospects for eradication. J. Clin. Invest. 2008, 118, 1266-1276. [CrossRef] [PubMed]

3. World Health Organization Leishmaniasis Fact Sheet. Available online: https://www.who.int/news-room/ fact-sheets/detail/leishmaniasis (accessed on 11 June 2020).

4. Burza, S.; Croft, S.L.; Boelaert, M. Leishmaniasis. Lancet 2018, 392, 951-970. [CrossRef]

5. Ribeiro-de-Jesus, A.; Almeida, R.P.; Lessa, H.; Bacellar, O.; Carvalho, E.M. Cytokine profile and pathology in human leishmaniasis. Braz. J. Med. Biol. Res. 1998, 31, 143-148. [CrossRef]

6. Croft, S.; Yardley, V. Chemotherapy of leishmaniasis. Curr. Pharm. Des. 2002, 8, 319-342. [CrossRef]

7. Haldar, A.K.; Sen, P.; Roy, S. Use of antimony in the treatment of leishmaniasis: Current status and future directions. Mol. Biol. Int. 2011, 2011, 1-23. [CrossRef]

8. Uliana, S.R.B.; Trinconi, C.T.; Coelho, A.C. Chemotherapy of leishmaniasis: Present challenges. Parasitology 2018, 145, 464-480. [CrossRef]

9. Leite, J.R.S.A.; Silva, L.P.; Rodrigues, M.I.S.; Prates, M.V.; Brand, G.D.; Lacava, B.M.; Azevedo, R.B.; Bocca, A.L.; Albuquerque, S.; Bloch, C. Phylloseptins: A novel class of anti-bacterial and anti-protozoan peptides from the Phyllomedusa genus. Peptides 2005, 26, 565-573. [CrossRef]

10. Kückelhaus, S.; Leite, J.R.S.A.; Neves, M.P.; Frota, K.S.; Abdala, L.F.; Muniz-Junqueira, M.I.; Bloch, C.; Tosta, C.E. Toxicity evaluation to mice of phylloseptin-1, an antimicrobial peptide from the skin secretion of Phyllomedusa hypochondrialis (Amphibia). Int. J. Pept. Res. Ther. 2007, 13, 423-429. [CrossRef]

11. Chernysh, S.; Kim, S.I.; Bekker, G.; Pleskach, V.A.; Filatova, N.A.; Anikin, V.B.; Platonov, V.G.; Bulet, P. Antiviral and antitumor peptides from insects. Proc. Natl. Acad. Sci. USA 2002, 99, 12628-12632. [CrossRef]

12. Peschel, A. How do bacteria resist human antimicrobial peptides? Trends Microbiol. 2002, 10, 179-186. [CrossRef]

13. Lee, D.G.; Shin, S.Y.; Kim, D.-H.; Seo, M.Y.; Kang, J.H.; Lee, Y.; Kim, K.L.; Hahm, K.-S. Antifungal mechanism of a cysteine-rich antimicrobial peptide, Ib-AMP1, from Impatiens balsamina against Candida albicans. Biotechnol. Lett. 1999, 21, 1047-1050. [CrossRef]

14. Ghosh, J.K.; Shaool, D.; Guillaud, P.; Cicéron, L.; Mazier, D.; Kustanovich, I.; Shai, Y.; Mor, A. Selective cytotoxicity of dermaseptin S3 toward Intraerythrocytic Plasmodium falciparum and the underlying molecular basis. J. Biol. Chem. 1997, 272, 31609-31616. [CrossRef] [PubMed]

15. Brand, G.D.; Leite, J.R.S.A.; Silva, L.P.; Albuquerque, S.; Prates, M.V.; Azevedo, R.B.; Carregaro, V.; Silva, J.S.; Sá, V.C.L.; Brandão, R.A.; et al. Dermaseptins from Phyllomedusa oreades and Phyllomedusa distincta: Anti-Trypanosoma cruzi activity without cytotoxicity to mammalian cells. J. Biol. Chem. 2002, 277, 49332-49340. [CrossRef] [PubMed]

16. Amiche, M.; Ladram, A.; Nicolas, P. A consistent nomenclature of antimicrobial peptides isolated from frogs of the subfamily Phyllomedusinae. Peptides 2008, 29, 2074-2082. [CrossRef] [PubMed]

17. Kückelhaus, S.A.S.; Leite, J.R.S.A.; Muniz-Junqueira, M.I.; Sampaio, R.N.; Bloch, C.; Tosta, C.E. Antiplasmodial and antileishmanial activities of phylloseptin-1, an antimicrobial peptide from the skin secretion of Phyllomedusa azurea (Amphibia). Exp. Parasitol. 2009, 123, 11-16. [CrossRef]

18. Zhang, R.; Zhou, M.; Wang, L.; McGrath, S.; Chen, T.; Chen, X.; Shaw, C. Phylloseptin-1 (PSN-1) from Phyllomedusa sauvagei skin secretion: A novel broad-spectrum antimicrobial peptide with antibiofilm activity. Mol. Immunol. 2010, 47, 2030-2037. [CrossRef]

19. Lee, D.G.; Hahm, K.-S.; Shin, S.Y. Structure and fungicidal activity of a synthetic antimicrobial peptide, P18, and its truncated peptides. Biotechnol. Lett. 2004, 26, 337-341. [CrossRef]

20. Raja, Z.; André, S.; Piesse, C.; Sereno, D.; Nicolas, P.; Foulon, T.; Oury, B.; Ladram, A. Structure, antimicrobial activities and mode of interaction with membranes of novel phylloseptins from the painted-belly leaf frog, Phyllomedusa sauvagii. PLoS ONE 2013, 8, e70782. [CrossRef]

21. Waddell, W.J. A simple ultraviolet spectrophotometric method for the determination of protein. J. Lab. Clin. Med. 1956, 48, 311-314. 
22. Brand, G.D.; Ramada, M.H.S.; Manickchand, J.R.; Correa, R.; Ribeiro, D.J.S.; Santos, M.A.; Vasconcelos, A.G.; Abrão, F.Y.; Prates, M.V.; Murad, A.M.; et al. Intragenic antimicrobial peptides (IAPs) from human proteins with potent antimicrobial and anti-inflammatory activity. PLOS ONE 2019, 14, e0220656. [CrossRef] [PubMed]

23. Lamiable, A.; Thévenet, P.; Rey, J.; Vavrusa, M.; Derreumaux, P.; Tufféry, P. PEP-FOLD3: Faster de novo structure prediction for linear peptides in solution and in complex. Nucleic Acids Res. 2016, 44, W449-W454. [CrossRef] [PubMed]

24. Teixeira, M.C.A.; de Jesus Santos, R.; Sampaio, R.; Pontes-de-Carvalho, L.; dos-Santos, W. A simple and reproducible method to obtain large numbers of axenic amastigotes of different Leishmania species. Parasitol. Res. 2002, 88, 963-968. [CrossRef]

25. Muniz-Junqueira, M.I.; Peçanha, L.M.F.; da Silva-Filho, V.L.; de Almeida Cardoso, M.C.; Tosta, C.E. Novel microtechnique for assessment of postnatal maturation of the phagocytic function of neutrophils and monocytes. Clin. Diagn. Lab. Immunol. 2003, 10, 1096-1102. [CrossRef] [PubMed]

26. Green, L.C.; Wagner, D.A.; Glogowski, J.; Skipper, P.L.; Wishnok, J.S.; Tannenbaum, S.R. Analysis of nitrate, nitrite, and [15N]nitrate in biological fluids. Anal. Biochem. 1982, 126, 131-138. [CrossRef]

27. Pick, E.; Keisari, Y. A simple colorimetric method for the measurement of hydrogen peroxide produced by cells in culture. J. Immunol. Methods 1980, 38, 161-170. [CrossRef]

28. Nathan, C. Nitric oxide as a secretory product of mammalian cells. FASEB J. 1992, 6, 3051-3064. [CrossRef]

29. Archer, S. Measurement of nitric oxide in biological models. FASEB J. 1993, 7, 349-360. [CrossRef]

30. Kückelhaus, C.S.; Kückelhaus, S.A.S.; Tosta, C.E.; Muniz-Junqueira, M.I. Pravastatin modulates macrophage functions of Leishmania (L.) amazonensis-infected BALB/c mice. Exp. Parasitol. 2013, 134, 18-25. [CrossRef]

31. Henry, Y.; Ducrocq, C.; Drapier, J.C.; Servent, D.; Pellat, C.; Guissani, A. Nitric oxide, a biological effector. Electron paramagnetic resonance detection of nitrosyl-iron-protein complexes in whole cells. Eur. Biophys. J. 1991, 20, 1-15. [CrossRef]

32. Williamson, P.; Schlegel, R.A. Back and forth: The regulation and function of transbilayer phospholipid movement in eukaryotic cells. Mol. Membr. Biol. 1994, 11, 199-216. [CrossRef] [PubMed]

33. Sansom, M.S.P. Alamethicin and related peptaibols - model ion channels. Eur. Biophys. J. 1993, 22. [CrossRef]

34. Dathe, M.; Meyer, J.; Beyermann, M.; Maul, B.; Hoischen, C.; Bienert, M. General aspects of peptide selectivity towards lipid bilayers and cell membranes studied by variation of the structural parameters of amphipathic helical model peptides. Biochim. Biophys. Acta 2002, 1558, 171-186. [CrossRef]

35. Brand, G.D.; Leite, J.R.S.A.; de Sá Mandel, S.M.; Mesquita, D.A.; Silva, L.P.; Prates, M.V.; Barbosa, E.A.; Vinecky, F.; Martins, G.R.; Galasso, J.H.; et al. Novel dermaseptins from Phyllomedusa hypochondrialis (Amphibia). Biochem. Biophys. Res. Commun. 2006, 347, 739-746. [CrossRef]

36. Pérez-Payá, E.; Houghten, R.A.; Blondelle, S.E. Determination of the secondary structure of selected melittin analogues with different haemolytic activities. Biochem. J. 1994, 299, 587-591. [CrossRef]

37. Tenenholz, T.C.; Klenk, K.C.; Matteson, D.R.; Blaustein, M.P.; Weber, D.J. Structural determinants of scorpion toxin affinity: The charybdotoxin $(\alpha-\mathrm{KTX})$ family of K+-channel blocking peptides. Rev. Physiol. Biochem. Pharmacol. 2000, 140, 135-185. [CrossRef] [PubMed]

38. Rinaldi, A.C.; Mangoni, M.L.; Rufo, A.; Luzi, C.; Barra, D.; Zhao, H.; Kinnunen, P.K.J.; Bozzi, A.; Giulio, A.D.; Simmaco, M. Temporin L: Antimicrobial, haemolytic and cytotoxic activities, and effects on membrane permeabilization in lipid vesicles. Biochem. J. 2002, 368, 91-100. [CrossRef]

39. El Amri, C.; Lacombe, C.; Zimmerman, K.; Ladram, A.; Amiche, M.; Nicolas, P.; Bruston, F. The plasticins: Membrane adsorption, lipid disorders, and biological activity. Biochemistry 2006, 45, 14285-14297. [CrossRef]

40. Dolis, D.; Moreau, C.; Zachowski, A.; Devaux, P.F. Aminophospholipid translocase and proteins involved in transmembrane phospholipid traffic. Biophys. Chem. 1997, 68, 221-231. [CrossRef]

41. Matsuzaki, K. Why and how are peptide-lipid interactions utilized for self-defense? Magainins and tachyplesins as archetypes. Biochim. Biophys. Acta 1999, 1462, 1-10. [CrossRef]

42. Ilgoutz, S.C.; McConville, M.J. Function and assembly of the Leishmania surface coat. Int. J. Parasitol. 2001, 31, 899-908. [CrossRef]

43. Guerrero, E.; Saugar, J.M.; Matsuzaki, K.; Rivas, L. Role of positional hydrophobicity in the leishmanicidal activity of magainin 2. Antimicrob. Agents Chemother. 2004, 48, 2980-2986. [CrossRef] [PubMed] 
44. Resende, J.M.; Moraes, C.M.; Prates, M.V.; Cesar, A.; Almeida, F.C.L.; Mundim, N.C.C.R.; Valente, A.P.; Bemquerer, M.P.; Piló-Veloso, D.; Bechinger, B. Solution NMR structures of the antimicrobial peptides phylloseptin-1,-2, and -3 and biological activity: The role of charges and hydrogen bonding interactions in stabilizing helix conformations. Peptides 2008, 29, 1633-1644. [CrossRef] [PubMed]

45. Ehrenstein, G.; Lecar, H. Electrically gated ionic channels in lipid bilayers. Quart. Rev. Biophys. 1977, 10, 1-34. [CrossRef]

46. Probst, C.M.; Silva, R.A.; B Menezes, J.P.; Almeida, T.F.; Gomes, I.N.; Dallabona, A.C.; Ozaki, L.S.; Buck, G.A.; Pavoni, D.P.; Krieger, M.A.; et al. A comparison of two distinct murine macrophage gene expression profiles in response to Leishmania amazonensis infection. BMC Microbiol. 2012, 12, 22. [CrossRef] [PubMed]

47. Muniz-Junqueira, M.I.; de Paula-Coelho, V.N. Meglumine antimonate directly increases phagocytosis, superoxide anion and TNF- $\alpha$ production, but only via TNF- $\alpha$ it indirectly increases nitric oxide production by phagocytes of healthy individuals, in vitro. Int. Immunopharmacol. 2008, 8, 1633-1638. [CrossRef]

48. Stamper, B.D.; Davis, M.; Scott-Collins, S.; Tran, J.; Ton, C.; Simidyan, A.; Roberts, S.C. Model-based evaluation of gene expression changes in response to Leishmania infection. Gene Regul. Syst. Biol. 2019, 13, 117762501982835. [CrossRef]

49. Conceição-Silva, F.; Morgado, F.N. Leishmania Spp-host interaction: There is always an onset, but is there an end? Front. Cell. Infect. Microbiol. 2019, 9, 330. [CrossRef]

50. Loeuillet, C.; Bañuls, A.-L.; Hide, M. Study of Leishmania pathogenesis in mice: Experimental considerations. Parasit. Vectors 2016, 9, 144. [CrossRef]

51. Fernandes, M.C.; Dillon, L.A.L.; Belew, A.T.; Bravo, H.C.; Mosser, D.M.; El-Sayed, N.M. Dual transcriptome profiling of Leishmania-infected human macrophages reveals distinct reprogramming signatures. mBio 2016, 7, e00027-16. [CrossRef]

52. de Saldanha, R.R.; Martins-Papa, M.C.; Sampaio, R.N.R.; Muniz-Junqueira, M.I. Meglumine antimonate treatment enhances phagocytosis and TNF- $\alpha$ production by monocytes in human cutaneous leishmaniasis. Trans. R. Soc. Trop. Med. Hyg. 2012, 106, 596-603. [CrossRef]

53. Kaye, P.; Scott, P. Leishmaniasis: Complexity at the host-pathogen interface. Nat. Rev. Microbiol. 2011, 9 , 604-615. [CrossRef]

54. Watford, W.T.; Hissong, B.D.; Bream, J.H.; Kanno, Y.; Muul, L.; O'Shea, J.J. Signaling by IL-12 and IL-23 and the immunoregulatory roles of STAT4. Immunol. Rev. 2004, 202, 139-156. [CrossRef] [PubMed]

55. McDyer, J.F.; Wu, C.Y.; Seder, R.A. The regulation of IL-12: Its role in infectious, autoimmune, and allergic diseases. J. Allergy Clin. Immunol. 1998, 102, 11-15. [CrossRef] [PubMed]

56. Chehimi, J.; Starr, S.E.; Frank, I.; D'Andrea, A.; Ma, X.; MacGregor, R.R.; Sennelier, J.; Trinchieri, G. Impaired interleukin 12 production in human immunodeficiency virus-infected patients. J. Exp. Med. 1994, 179, 1361-1366. [CrossRef] [PubMed]

57. Tait Wojno, E.D.; Hunter, C.A.; Stumhofer, J.S. The Immunobiology of the Interleukin-12 Family: Room for Discovery. Immunity 2019, 50, 851-870. [CrossRef] [PubMed]

(C) 2020 by the authors. Licensee MDPI, Basel, Switzerland. This article is an open access article distributed under the terms and conditions of the Creative Commons Attribution (CC BY) license (http://creativecommons.org/licenses/by/4.0/). 